\title{
Arecoline, Hesperidin and Trifluoperazine-mediated Cytotoxicity and Cell Death Potential in NIH/3T3 Fibroblasts Cells -Toxicity/Safety Assessment in a NIH/3T3 Model Fibroblast Cell Line
}

\author{
Vembuli A Varadharaj', Suresh $\mathbf{P K}^{2, *}$ \\ Department of Biomedical Sciences, School of Biosciences and Technology, VIT, Vellore, Tamil Nadu, INDIA.
}

\begin{abstract}
Aim/Background: Arecoline is considered to be the principal etiologic agent for Oral Sub mucous Fibrosis (OSF) with the buccal fibroblasts being the major target. Hence, this model alkaloid has been used to evaluate toxicity and cell death potential in NIH/3T3 cells and compared with that of Hesperidin. Materials and Methods: Toxicity and cell death, for the two molecules, was tested using a battery of assays (MTT assay based cytotoxicity assessment; $\mathrm{AO} / \mathrm{EtBr}$ assay-based determination of the percentage of dead cells; PI-based cell-cycle and cell death analysis using flow cytometry; DCFH-DA-based ROS levels). We also evaluated the role of S100A4 in this process using Trifluoperazine (TFP)- an antagonist of this protein. These experiments involved challenging the cells with arecoline and protecting them with Hesperidin and TFP separately. Results: IC $_{50}$ measurements, based on the MTT assay, were found to be $38 \mu \mathrm{M}$ and 7.5 Micromolar respectively. Based on the $\mathrm{AO} / \mathrm{EtBr}$ and the flow cytometry assay, both the chemicals exhibited a dose-dependent increase in cell death. Both chemicals arrested the cells in different phases of the cell cycle. Arecoline and Hesperidin altered ROS levels in a dosedependent manner. Our challenge-protection experiments showed that Hesperidin and TFP, were able to reduce the arecoline-mediated cell death in NIH/3T3 fibroblasts. These results may due to an alteration in the ROS levels, despite quantitative differences in their cytotoxicity and cell death potential. The protection-challenge experiments showed that Arecoline and TFP may have a marginal cytoprotective effect. Conclusions: Our results substantiates and validates our experimental design to evaluate the toxicity and safety of model fibrotic chemicals as well as test the probable protective effects conferred by Hesperidin-like natural molecules as well as possibly address mechanistic issues pertaining to ROS as well as S100A4 antagonism using TFP and related molecules.
\end{abstract}

Key words: Arecoline, Hesperidin, Trifluoperazine, S100A4, Cell Death, ProtectionChallenge, Challenge-Protection.

\section{INTRODUCTION}

Arecoline is an important alkaloid found in areca nut (a component of betel quid). Results from various in vitro model systems have shown this chemical agent to be a model genotoxic and cytotoxic compound ${ }^{1}$ that induces apoptosis, ${ }^{2}$ inhibition of p53 and repression of DNA repair. ${ }^{3,4}$ Also, an in vivo study has demonstrated chromosome breakage. ${ }^{5}$ Another report has documented that a related molecule (arecoline $\mathrm{N}$-oxide) increased S100A4 (a member of the metastasis-related proteins in the calcium binding protein family and also used to identify cells of the fibroblast lineage) levels in cultured oral fibroblasts, ${ }^{6}$ thereby substantiating the inclusion of this marker protein in this safety assessment study of ours. Also, this protein was found to be elevated in buccal fibroblasts in ex vivo and in vitro studies. ${ }^{8}$ Flavonoids constitute
Submission Date: 24-04-2020; Revision Date: 29-05-2020; Accepted Date: 02-07-2020

DOI: 10.5530/ijper.54.3s.153 Correspondence: Dr. PK Suresh PHAG, Department of Biomedical Sciences, School of Biosciences and Technology VIT, Vellore, Vellore-632014, Tamil Nadu, INDIA.

Phone: +91 9444047684

E-mail: p.k.suresh@vit.ac.in

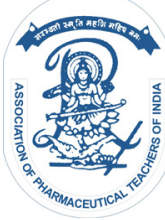

www.ijper.org 
an important, category of bioactive molecules whose antioxidant property may play a pivotal role in free radical scavenging as well in altering the redox status in terms of the enzymic antioxidants ${ }^{9}$ and prevents many diseases including various types of cancer. ${ }^{10}$ Hesperidin, is an important flavonoid with various biological activities in different experimental systems, not necessarily restricted to those modelling cancer. These activities include inhibition of proliferation; apoptosis ${ }^{11}$ and anti-oxidant property. ${ }^{12,13}$ Despite the reported inferential involvement of S100A4 protein in buccal fibroblasts in arecoline-mediated effects, our experimental design is the first of its kind (involving a combination of MTT and Propidium Iodide (PI)based cytotoxicity as well as cell death assays), wherein a chemical antagonist has been used to evaluate the role of this protein in arecoline and hesperidin-mediated toxic effects. Further, we report, for the first time, a comparative assessment of the relative toxicity and cell death potential of Arecoline, Hesperidin and Trifluoperazine in NIH/3T3 fibroblasts - a model, fibroblast cell line of murine origin, that has been used in several studies, since it was developed as a cell line in 1963. ${ }^{14}$ Also, this cell line has been used in performing the classical MTT-based cytotoxicity studies (an assay also adopted in our study). ${ }^{15}$

\section{MATERIALS AND METHODS}

\section{Reagents}

Arecoline Hydro bromide (Molecular weight - 236) (Product of Switzerland) was procured from Sigma Aldrich and Hesperidin from Himedia. Stock solutions of both the chemicals were prepared in sterile DMSO and diluted for use in serum-free medium. Propidium Iodide (PI) (Himedia); MTT (Himedia); Acridine orange (Himedia); Ethidium bromide (Himedia) and 2', 7-Dichlorofluorescin diacetate (Sigma- Product of Israel) and Phosphate Buffered Saline.

\section{Cell Culture}

NIH/3T3 fibroblasts cell line (Passage No.21) was purchased from NCCS, Pune and were cultured in Dulbecco's modified Eagle's medium (Himedia) supplemented with 10\% FBS (Himedia). Additionally, an antibiotic solution (100X) containing 10,000 IU Penicillin; $10 \mathrm{mg}$ Streptomycin; $25 \mu \mathrm{g}$ Amphotericin B/ $\mathrm{ml}$ were added as media supplements. The cells were incubated at $37^{\circ} \mathrm{C}$ in a humidified incubator with $5 \%$ $\mathrm{CO}_{2}$.

\section{Cytotoxic Effect of Arecoline, Hesperidin and Trifluoperazine (TFP) on NIH/3T3 fibroblasts cells}

The MTT cytotoxicity assay protocol followed was as described in the paper ${ }^{15}$ with a few modifications as stated below: Ten thousand $\left(1 \times 10^{4}\right)$ cells were grown in a 96 well plate. After 24 hrs, cells were exposed to different concentrations of Arecoline $(0-100 \mu \mathrm{M} / \mathrm{ml})$; Hesperidin $(0-100 \mu \mathrm{M} / \mathrm{ml})$ and Trifluoperazine $(0-10$ $\mu \mathrm{M} / \mathrm{ml})$. After $24 \mathrm{hr}$ of incubation, a couple of PBS washes were done and then the medium containing 0.5 $\mathrm{mg} / \mathrm{ml}$ of MTT was added. The duration of exposure to MTT was for 4 hours. This chemical when reduced, forms the formazan crystals that are dissolved using DMSO. Cell viability was measured by determining O.D at $540 \mathrm{~nm}$. Absorbance values were based on the increasing concentrations of the solutions containing

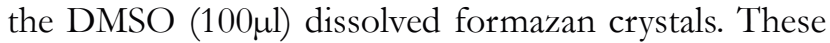
values were representative of and were an indirect measure of the functionality of $\mathrm{NAD}(\mathrm{P}) \mathrm{H}$-dependent cellular oxidoreductases. ${ }^{16}$ Results represent the average values and the standard deviations from the independent experiments performed three times. The negative controls were the untreated cells. The positive and vehicle controls (PC\&VC) were respectively $1 \mu \mathrm{M}$-Doxorubicin; and the DMSO. In this context, it was ensured that the final concentration of DMSO did not increase beyond $1 \%$ in each of our drug/toxicanttreated cultures.

\section{Cell death detection by Acridine Orange (AO) and Ethidium bromide (EtBr) method ( $\mathrm{AO} / \mathrm{EtBr}$ method)}

Acridine orange and Ethidium bromide is a simple, rapid and accurate method to detect cell death. Acridine Orange (AO) invades all the cells and stains the nuclei which appear green (those with and without an intact plasma membrane). The other dye Ethidium bromide (EB) stains nuclei (red colour) of only those cells, which have lost the integrity of the cytoplasmic membrane. Thus, the nucleus of the early apoptotic cells appear bright green due to chromatin condensation and the late apoptotic cells exhibit an orange-stained chromatin. ${ }^{17}$ The $\mathrm{AO} / \mathrm{EtBr}$ cell death detection assay protocol ${ }^{32}$ followed was as described in the paper cited, with a few modifications as stated below: $1 \times 10^{4}$ Cells were seeded in a 6-well plate. After cell growth for a day, they were exposed to different concentrations of Arecoline $(0,19,38$ and $76 \mu \mathrm{M})$ and Hesperidin $(0,3.75,7.5$ and $15 \mu \mathrm{M})$. The concentrations selected were based on the reproducible $\mathrm{IC}_{50}$ measurements made using the MTT- 
based cytotoxicity assay. After treatment of the cells for a day, the cells were washed with Dulbecco's PBS and fixed with $4 \%$ paraformaldehyde. Staining of the fixed cells was then done with a solution containing $50 \mu \mathrm{g} /$ $\mathrm{ml}$ of $\mathrm{AO}$ as well as $50 \mu \mathrm{g} / \mathrm{ml}$ of $\mathrm{EtBr}$ at a ratio of 1:1. The cells were left in this staining solution for 15 min at. After incubation, the cells were washed a couple of times with PBS and then the cells were visualized under the fluorescence microscope (Carl Zeiss, AXIO, Germany). The excitation and emission maxima for $\mathrm{AO} / \mathrm{EtBr}$ were $525 \mathrm{~nm}$ and $650 \mathrm{~nm}$ respectively). Hence, the filters used were green and red) Different fields were selected randomly and one hundred cells were counted for each of the concentrations of arecoline.

\section{Cell Cycle Analysis by Flow Cytometry}

The flow cytometry-based cell cycle analysis was done based on the method described $i^{18}$ with a few modifications as stated below:

$1 \times 10^{4}$ Cells were grown in a 6-well plate. After growing the cells for a day, cells were exposed to various concentrations of Arecoline $(0,19,38$ and $76 \mu \mathrm{M})$ and Hesperidin $(0,3.75,7.5$ and $15 \mu \mathrm{M})$ along with $1 \mu \mathrm{M}$ Doxorubicin; $1 \%$ DMSO and untreated media as the positive; vehicle and negative controls respectively. The concentrations selected were based on the MTT assaybased reproducible $\mathrm{IC}_{50}$ values. After $24 \mathrm{hr}$ of treatment, cells were washed with Dulbecco's PBS and then taken up in $0.5 \mathrm{ml}$ PBS and the cell suspension was fixed in $70 \%$ ethanol for $30 \mathrm{~min}$ at $4^{\circ} \mathrm{C}$. Then, $2.5 \mathrm{ml}$ of PBS was added and the cell suspensions were centrifuged. The respective supernatants were discarded and cells were again resuspended with $2.5 \mathrm{ml}$ of PBS and the pellets were stored in ice. Then the pellets were incubated with $20 \mu \mathrm{g} / \mathrm{ml}$ of DNA staining solution (PI) containing $0.2 \mathrm{mg}$ DNase free RNase. ${ }^{19}$ Cells were incubated for $30 \mathrm{~min}$ at room temperature and analysed using our in-house flow cytometer (Beckman coulter cytoflex) and the results were analysed using the cytexpert software.

\section{Live and Dead analysis by Flow Cytometry}

The flow cytometry-based live and dead analysis was performed based on the method described in $^{20}$ with a few modifications as stated below:

$1 \times 10^{4}$ Cells were grown in a 6 -well plate. After $24 \mathrm{hr}$, the cells were exposed to various concentrations of Arecoline $(0,19,38$ and $76 \mu \mathrm{M})$ and Hesperidin $(0$, $3.75,7.5$ and $15 \mu \mathrm{M})$. The concentrations selected were based on the MTT assay-based reproducible $\mathrm{IC}_{50}$ values. After exposure of these cells for $24 \mathrm{hr}$, the cells were washed with Dulbecco's PBS. Then, the cells were harvested and the pellet was then suspended with 0.5 $\mathrm{ml}$ of PBS. Then, a $5 \mu \mathrm{l}(50 \mu \mathrm{g} / \mathrm{ml})$ solution of PI was added and incubated for $5 \mathrm{~min}$ in the dark at room temperature. ${ }^{20}$ Then, the cells were analysed using our in-house flow cytometer (details provided above) and the results were analysed using the Flowjo software.

\section{Measurement of ROS using DCFDA}

The DCFH-DA-based total intracellular ROS measurements were done based on the method described in ${ }^{21}$ with a few modifications as stated below: $1 \times 10^{4}$ Cells were grown in a 6 -well plate. After a day, the cells were exposed to various concentrations of Arecoline $(0,19,38$ and $76 \mu \mathrm{M})$ and Hesperidin $(0,3.75$, 7.5 and $15 \mu \mathrm{M})$ respectively. After 24 hrs of treatment, cells were washed with Dulbecco's PBS. Then the cells were treated with $5 \mu \mathrm{g} / \mathrm{ml}$ of 2', 7'-dichlorofluorescin diacetate (DCFDA; Sigma) for a 15 min time period. The cell suspension was washed with PBS and lysed in RIPA buffer. ${ }^{22}$ The fluorescence was detected spectrophotometrically at $510 \mathrm{~nm}$.

\section{Challenge and Protection and Protection and Challenge, Cytotoxicity and cell death analysis}

As in the case for Arecoline and Hesperidin, the concentrations of Trifluoperazine were selected based on our preliminary MTT assay-based reproducible $\mathrm{IC}_{50}$ value determinations.

\section{MTT Assay}

One lakh $\left(1 \times 10^{5}\right)$ cells were grown in a 96 well plate. After growth of these cells for a day, the cells were pre-treated with different concentrations of Arecoline $(0,19,38 \mu \mathrm{M} / \mathrm{ml})$, Hesperidin $(0,3.75,7.5 \mu \mathrm{M})$ and Trifluoperazine (TFP- 0, 1.1 and $2.2 \mu \mathrm{M}$ ). After $24 \mathrm{hrs,}$ the cells were challenged with different concentrations of Arecoline $(0,19,38 \mu \mathrm{M})$; Hesperidin $(0,3.75,7.5$ $\mu \mathrm{M})$ and Trifluoperazine (TFP- 0, 1.1 and $2.2 \mu \mathrm{M}$ ) for $24 \mathrm{hrs}$. Then, the cells were washed twice with Dulbecco's PBS. Then, the medium was exposed to $0.5 \mathrm{mg} / \mathrm{ml}$ of MTT for $4 \mathrm{hrs}$. Absorbance values were based on the increasing concentrations of the solutions containing the DMSO $(100 \mu \mathrm{l})$-dissolved formazan crystals. These values were representative of and were an indirect measure of the functionality of the NAD $(P)$ H-dependent cellular oxidoreductases. ${ }^{15}$ Results represent the average values and the standard deviations from independent experiments performed thrice. The negative controls were the untreated cells. The positive and vehicle controls (PC\&VC) were respectively 1 $\mu \mathrm{M}$-Doxorubicin; and the DMSO. In this context, it was ensured that the final concentration of DMSO did 
not increase beyond $1 \%$ in each of our drug/toxicanttreated cultures.

\section{Live and Dead analysis by Flow Cytometry}

The flow cytometry-based live and dead analysis was done based on the method described in ${ }^{20}$ with a few modifications as stated below:

One lakh $\left(1 \times 10^{5}\right)$ cells were grown in a 96 well plate. After 24 hrs, the cells were pre-treated with different concentrations of Arecoline $(0,19$ and $38 \mu \mathrm{M})$, Hesperidin $(0,3.75$ and $7.5 \mu \mathrm{M})$ and Trifluoperazine (TFP- 0, 1.1 and $2.2 \mu \mathrm{M}$ ). After $24 \mathrm{hr}$, the cells were challenged with different concentrations of Arecoline $(0,19,38 \mu \mathrm{M})$; Hesperidin $(0,3.75,7.5 \mu \mathrm{M})$ and Trifluoperazine (TFP- 0, 1.1 and $2.2 \mu \mathrm{M}$ ). Then, the cells were washed twice with Dulbecco's PBS. The washed cells were harvested and centrifuged and then, the cell pellet was suspended in $0.5 \mathrm{ml}$ of PBS. Then, a $5 \mu \mathrm{l}$ of a $50 \mu \mathrm{g} / \mathrm{ml}$ of PI solution was added and the cultures were kept in the dark for $5 \mathrm{~min}$ at room temperature. Then, the cells were analysed using our in-house flow cytometer (details provided above) and the results were analysed using the FlowJo software (as mentioned earlier).

\section{RESULTS}

\section{Cytotoxic Effect of Arecoline on NIH/3T3 fibroblasts cells}

NIH/3T3 Cells were exposed to medium containing Arecoline $(0-100 \mu \mathrm{M})$ for $24 \mathrm{hr}$. The inhibitory effects of Arecoline, on the proliferation capabilities of these cells, were evaluated by the MTT cell viability assay. As shown in Figure 1, Arecoline (0.5, 1, 2, 5, 10, 20, 50 and 100 Micromolar) treatment of NIH/3T3 resulted in a dose-dependent reduction in cell viability, in comparison with the Negative as well as the vehicle control (DMSO) values. The calculated $\mathrm{IC}_{50}$ value for Arecoline was $38 \mu \mathrm{M}(\mathrm{N}=3)$.

MT'T results, we selected two different concentrations $\left(\mathrm{IC}_{25}-19 \mu \mathrm{M}, \mathrm{IC}_{50}-38 \mu \mathrm{M}\right.$ and $\mathrm{IC}_{100}-76$ Micromolar $)$ of Arecoline for our further experiments (Figure 1). Our report is, to the best of our knowledge, the first of its kind wherein arecoline-mediated cytotoxicity has been assessed specifically in NIH/ 3T3 cells based on our MT'T assay-based cytotoxicity data. Further, the differences in cytotoxicity based on the site of origin of the fibroblasts as well as cell line-based variants again substantiates the need to systematically evaluate toxicity/safety in cells that are representative of normal fibroblasts. A similar rationale was adopted for determination of the $\mathrm{IC}_{50}$ value in the case of Hesperidin (details provided below).

\section{Cytotoxic effect of Hesperidin on NIH/3T3 Fibroblasts}

In this study, we wanted to examine the protective and pro-survival effects of Hesperidin subsequent to Arecoline pre-treatment of NIH/3T3 fibroblasts. Hence, it was imperative to evaluate the cytotoxic concentration range of hesperidin in NIH/3T3 fibroblasts. Different concentrations between 0 and $100 \mu \mathrm{M}$ were tested for this purpose. Currently, data pertaining to MT'T assay-based cytotoxicity assay is scanty and has been performed in other cell lines. Specifically, there is a report wherein differential cytotoxicity has been demonstrated in cancerous epithelial cells, while the non-tumorigenic fibroblasts were not affected. ${ }^{47}$ Hesperidin treatment resulted in a diminution of cell viability in a dose-dependent manner, compared with untreated and vehicle controls. The calculated $\mathrm{IC}_{50}$ for Hesperidin is $7.5 \mu \mathrm{M}$ (Figure $2-\mathrm{N}=3$ ). This finding with respect to the cytotoxicity data has not been hitherto reported specifically for 3T3 cells. Positive control showed $30 \%$ viability. Based on the $\mathrm{IC}_{50}$ values, we selected three different $(3.75,7.5$ and $15 \mu \mathrm{M}$ concentrations of Hesperidin for our further experiments.

\section{Cell death detection by Acridine Orange and Ethidium bromide method}

The results of this assay, to discriminate apoptotic from necrotic cells, have been depicted (Figure 3) in the form of fluorescence images (Figure 3) as well as a graphical representation (Figure 4). The numbers in parenthesis refers to the individual bars in the graph (Figure 4) and is sequential.

Figure 3a (Figure 4 A(1)) Positive control showed $90 \%$ of cell death (late apoptosis). Here we showed a dose-dependent effect for Arecoline, when compared with the control data (Negative and Vehicle Control respectively-Figure 3b and Figure 3c (Figure 4A (2 and 3)). The majority of cells (Negative and Vehicle controls) were stained green in colour and hence, were healthy (as per the existing nomenclature). Arecoline (Figure 3d (Figure 4A (4)) at a concentration of showed around $20-25 \%, 38 \mu \mathrm{M}$ (Figure 3e (Figure 5 (5)) showed $40-45 \%$ and $76 \mu \mathrm{M}$ (Figure 3f (Figure 4A (6)) showed that around $68-70 \%$ of the cells were undergoing early apoptosis. However, there were a few cells that showed late apoptosis, after the cells were exposed with Arecoline for $24 \mathrm{hr}(\mathrm{N}=2)$. Hesperidin showed a concentrationdependent cell death compared with the positive (Figure 4B (1)), Vehicle (Figure 4B (2)) and Negative controls

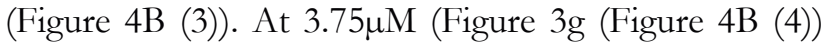
Hesperidin showed 25-30\%, 7.5 $\mu \mathrm{M}$ (Figure 3h (Figure 
$4 \mathrm{~B}$ (5)) showed $60-65 \%$ and $15 \mu \mathrm{M}$ (Figure $3 \mathrm{i}$ (Figure 4B (6)) showed $75-80 \%$ cell death. $(\mathrm{N}=2)$. These results suggest that Arecoline and Hesperidin was able to induce early and late apoptosis in NIH/3T3 fibroblasts cells in a manner that was dose-dependent (Figure 3 and Figure 4A; 4B -N=2).

\section{Cell Cycle Analysis by Flow Cytometry}

In this study, we examined arecoline-mediated pertubations in the NIH/3T3 cell cycle. For this purpose, NIH/3T3 cells were exposed to different concentrations of arecoline and the relative percentage distribution of cells at the different cell cycle phases were studied (Figure 5). Arecoline $19 \mu \mathrm{M}$, did not have a significant effect on the cells but $38 \mu \mathrm{M}$ (IC50) of arecoline treatment led to a $\mathrm{G} 1$ arrest and a shorter $\mathrm{S}$ phase and $76 \mu \mathrm{M}$ showed $\mathrm{G} 2 / \mathrm{M}$ block $(\mathrm{N}=1)$. Our data is at variance from that reported for arecoline-treated oral mucosal fibroblasts and is discussed below.

\section{Live and dead cell Analysis using PI by Flow Cytometry}

Arecoline is a known cytotoxic and genotoxic compound, which is known to induce cell death. Here we have examined the Arecoline-mediated cell death potential in $\mathrm{NIH} / 3 \mathrm{~T} 3$ fibroblasts. Positive control showed around $80 \%$ cell death and the negative and vehicle controls has showed no cell death. Arecoline-treated cells have shown dose-dependent cell death (Figure $6 \mathrm{~N}=1$ ).

\section{Intracellular ROS Detection by DCFDA Method}

We then wanted to evaluate the possible involvement of ROS in arecoline-mediated cytotoxicity, cell-cycle arrest and cell death in NIH/3T3 fibroblast cells (Figure 7 $\mathrm{N}=2$ ).

\section{Cell Cycle Analysis of Hesperidin}

Here we examined the effect of Hesperidin in NIH/3T3 fibroblasts. The positive control-treated cells (Figure 8 (1)) were able to block the cell cycle significantly at G2/M phase and Vehicle (Figure 8 (2)) and negative control (Figure 8 (3)) showed no effect on cell cycle. Hesperidin $3.75 \mu \mathrm{M} / \mathrm{ml}$ (Figure 8 (4)), has no significant effect and all the cells were blocked in the G1/S phase. The higher concentrations of Hesperidin were also predominantly involved in blocking the cells in the G1 phase (Figure $8-\mathrm{N}=1$ ).

\section{Live and dead cell Analysis using Propidium lodide by Flow Cytometry}

Here we have examined the effect of hesperidin on the growth of NIH/3T3 fibroblasts. These cells exhibited a concentration-dependent inhibitory effect following exposure to Hesperidine (Figure 9-N=1). Positive control showed around 80\% cell death and the negative and vehicle controls has showed no cell death. Hesperidin treated cells (Figure 9 (4, 5 and 6)) have shown concentration dependent cell death.

\section{Intracellular Hesperidin-mediated ROS production (DCFH-DA assay)}

We report a concentration-dependent inhibition of ROS production in NIH3T3 cells (Figure $10 \mathrm{~N}=2$ ).

\section{Cytotoxic effect of Trifluoperazine (TFP) on $\mathrm{NIH} / 3 \mathrm{~T} 3$ fibroblasts}

Hence, we wanted to evaluate the possible role of TFP in ROS-mediated survival versus death of cultured NIH3T3 cells, based on evidence in the literature about its probable, protective role. Prior to performing the protection-challenge assay, it was necessary to determine the cytotoxicity of TFP. MTT assay-based results indicated that the IC50 for TFP was 2.2 (Figure $11 \mathrm{~N}=3$ ). This is the first report of its kind wherein we have reported the $\mathrm{IC}_{50}$ value for TFP in NIH/3T3 cells.

\section{MTT Challenge and Protection Assay}

Here we have examined the protective role of TFP and Hesperidin in NIH/3T3 fibroblasts. The toxicity percentages of the combinatorial treatments are given in Table 1. The challenge and protection data presented herein seems to indicate that TFP may improve the relative survival of NIH3T3 cells in comparison with that of Hesperidin (Figure 12 - comparison of 7 versus 6; comparison of 8 versus 9); Table 1 - Sl. No.6 versus 7; Sl. No. 8 versus $9 \mathrm{~N}=2$ ).

\section{Live and Dead Analysis using Flow-Cytometry (Challenge and Protection Assay)}

A similar correlatable result was observed in the case of the flow cytometry PI-based determination of live and dead cells Figure 13 - comparison of 7 versus 6; comparison of 8 versus 9); Table 2 - Sl. No.6 versus 7; Sl. No. 8 versus 9 in both tables $\mathrm{N}=1$ ). Despite quantitative differences in cytotoxicity and cell death potential, Hesperidin and TFP, were able to reduce the arecoline-mediated cell death in NIH/3T3 fibroblasts, by probably varying the ROS levels.

\section{MTT and Flow Cytometry Data: Protection and Challenge}

Both the assays Table 2 and 3 -comparison of Sl. No. 5 versus 6 in both tables $\mathrm{N}=2$ ) seem to indicate some change in the survival of NIH/3T3 cells with arecoline showing a slightly better cytoprotective effect. These results validate our experimental design. 


\section{DISCUSSION}

\section{Cytotoxic Effect of Arecoline on NIH/3T3 fibroblasts cells}

Our MTT assay-based cytotoxicity with a reproducible $\mathrm{IC}_{50}$ value of $38 \mu \mathrm{M}$ in NIH/3T3 cells has hitherto not been reported (Figure 1). Since data is not available in the literature specifically demonstrating arecoline-mediated cytotoxicity in NIH/3T3 cells, literature pertaining to its effects on human buccal mucosal fibroblasts as well as the 3T3-L1 pre-adipocytes as well as the 3T3-L1 adipocytes is discussed. A report involving Oral Mucosal Fibroblasts (OMF) has clearly shown that arecoline concentrations less than $200 \mu \mathrm{M}$ were not cytotoxic. The same paper has documented that there would be variability in the data based on cell density, concentration of serum and incubation time. Hence, this paper has provided a basis for the reported variability in the cytotoxicity data reported herein. ${ }^{23}$ Cytotoxic effect was
38 and $63 \%$ at the $200 \mu \mathrm{M}$ and $400 \mu \mathrm{M}$ concentration respectively, following arecoline treatment of human Buccal Mucosal Fibroblasts (BMF) cells. The effects of arecoline could be altered, when used in combination with experimental agents that vary the intracellular GSH thiol levels. ${ }^{24}$ In the case of human gingival fibroblasts, exposure to concentrations greater than $50 \mu \mathrm{g} / \mathrm{ml}$ of arecoline resulted in cytotoxic effects. ${ }^{25}$ This differential toxicity data may be attributable, at least in part, to differences in the thiol levels in fibroblasts isolated from different sites in the oral cavity in humans. However, the differences may also be attributable, in part, to different methods adopted for assessing cytotoxicity (DNA-intercalation-based method) as well as the use of primary cultures of human gingival fibroblasts. Work on 3T3-L1 adipocytes has shown that arecoline $(0,25,50$, $100 \mu \mathrm{mol} / \mathrm{L})$ did not produce toxicity in this cell line following a $72 \mathrm{hr}$ exposure. ${ }^{26}$ Another study has shown that arecoline's $\mathrm{IC}_{50}$ is relatively very high. Specifically,

Table 1: Challenge-Protection Experiments were done on NIH/3T3 cells and the MTT assay was performed. This table provides cytotoxicity data following exposure of NIH/3T3 cells to the different combinations of drugs/chemicals. The experimental design is explained in the methods section. Arecoline-mediated cytotoxicity was reduced by Hesperidin and TFP.

\begin{tabular}{|c|c|c|c|c|}
\hline S.No & Sample & $\begin{array}{c}\text { Day } 1 \\
24 \mathrm{hr}\end{array}$ & $\begin{array}{c}\text { Day } 2 \\
24 \mathrm{hr}\end{array}$ & $\%$ of Cytotoxicity \\
\hline 1 & Positive control & $0.5 \mu \mathrm{M}$ Doxorubicin & $0.5 \mu \mathrm{M}$ Doxorubicin & 39.35 \\
\hline 2 & Vehicle Control & $0.01 \% \mathrm{DMSO}$ & $0.01 \%$ DMSO & 1.05 \\
\hline 3 & Negative control & No drug & No drug & 0.6 \\
\hline 4 & Arecoline $\mathrm{IC}_{25}+$ Arecoline $\mathrm{IC}_{25}$ & Arecoline $\mathrm{IC}_{25}$ & Arecoline $\mathrm{IC}_{25}$ & 18.45 \\
\hline 5 & Arecoline $\mathrm{IC}_{50}+$ Arecoline $\mathrm{IC}_{50}$ & Arecoline $\mathrm{IC}_{50}$ & Arecoline $\mathrm{IC}_{50}$ & 24.2 \\
\hline 6 & Arecoline $\mathrm{IC}_{50}+$ Hesperidin $\mathrm{IC}_{25}$ & Arecoline $\mathrm{IC}_{50}$ & Hesperidin $\mathrm{IC}_{25}$ & 10.6 \\
\hline 7 & Arecoline $\mathrm{IC}_{50}+$ Hesperidin $\mathrm{IC}_{50}$ & Arecoline $\mathrm{IC}_{50}$ & Hesperidin $\mathrm{IC}_{50}$ & 15.75 \\
\hline 8 & Arecoline $\mathrm{IC}_{50}+\mathrm{TFP}-\mathrm{IC}_{25}$ & Arecoline $\mathrm{IC}_{50}$ & TFP-IC 25 & 6.8 \\
\hline 9 & Arecoline $\mathrm{IC}_{50}+\mathrm{TFP}-\mathrm{IC}_{50}$ & Arecoline $\mathrm{IC}_{50}$ & TFP-IC 50 & 4.2 \\
\hline
\end{tabular}

Table 2: Challenge-Protection Experiments were done on NIH/3T3 cells and the flow cytometry assay was performed. This table provides PI-based flow cytometry data following exposure of NIH/3T3 cells to the different combinations of drugs/chemicals. The experimental design is explained in the methods section. Arecoline-mediated cell death was reduced by Hesperidin and TFP.

\begin{tabular}{|c|c|c|c|c|c|}
\hline S.No & Sample & $\begin{array}{c}\text { Day } 1 \\
24 \mathrm{hr}\end{array}$ & $\begin{array}{c}\text { Day } 2 \\
24 \mathrm{hr}\end{array}$ & $\%$ of Live & $\%$ of Dead \\
\hline 1 & Positive control & $0.5 \mu \mathrm{M}$ Doxorubicin & $0.5 \mu \mathrm{M}$ Doxorubicin & 79.58 & 20.42 \\
\hline 2 & Vehicle Control & $0.01 \%$ DMSO & $0.01 \%$ DMSO & 98.98 & 1.02 \\
\hline 3 & Negative control & No drug & No drug & 99.63 & 0.37 \\
\hline 4 & Arecoline $\mathrm{IC}_{25}+$ ArecolinelC $\mathrm{C}_{25}$ & Arecoline $\mathrm{IC}_{25}$ & Arecoline $\mathrm{IC}_{25}$ & 85.98 & 14.02 \\
\hline 5 & Arecoline $\mathrm{IC}_{50}+$ ArecolinelC $_{50}$ & Arecoline $\mathrm{IC}_{50}$ & Arecoline $\mathrm{IC}_{50}$ & 82.04 & 17.96 \\
\hline 6 & Arecoline $\mathrm{IC}_{50}+$ Hesperidin $\mathrm{IC}_{25}$ & Arecoline $\mathrm{IC}_{50}$ & Hesperidin $\mathrm{IC}_{25}$ & 90.52 & 9.48 \\
\hline 7 & Arecoline $\mathrm{IC}_{50}+$ Hesperidin $\mathrm{IC}_{50}$ & Arecoline $\mathrm{IC}_{50}$ & Hesperidin $\mathrm{IC}_{50}$ & 88.10 & 11.90 \\
\hline 8 & Arecoline $\mathrm{IC}_{50}+\mathrm{TFP}-\mathrm{IC}_{25}$ & Arecoline $\mathrm{IC}_{50}$ & TFP-IC 25 & 93.14 & 6.86 \\
\hline 9 & Arecoline $\mathrm{IC}_{50}+\mathrm{TFP}-\mathrm{IC} \mathrm{C}_{50}$ & Arecoline $\mathrm{IC}_{50}$ & TFP-IC ${ }_{50}$ & 96.94 & 3.06 \\
\hline
\end{tabular}


the $\mathrm{IC}_{50}$ in $3 \mathrm{~T} 3-\mathrm{L} 1$ pre-adipocytes was $200 \sim 400 \mu \mathrm{M}$, following incubation of these cells with arecoline for 24 as well as $48 \mathrm{hr}$. Further, the $\mathrm{IC}_{50}$ decreased following a longer exposure period $72 \sim 120 \mathrm{hrs} .{ }^{27}$ The relative MTTbased cytotoxicity of Hesperidin was also determined using the same cell line. This flavonoid, present in several citrus fruits, ${ }^{28}$ was selected due to the reported antioxidan $\mathrm{t}^{29}$ and anticancer properties..$^{30,31}$ Our work is the first of its kind wherein a systematic comparison has been made in terms of the cytotoxicity of arecoline and hesperidin in NIH/3T3 cells. The remarkable difference in potency in terms of the $\mathrm{IC}_{50}$ value of $38 \mu \mathrm{M}$ and 7.5 $\mu \mathrm{M}$ respectively for arecoline and hesperidin has been demonstrated for the first time in our study. Further, this approach validates our methodology for our subsequent MT'T-based protection and challenge experiments. Also, this information about the toxicity range provides a sound scientific basis for the dose selection for our subsequent experiments.

\section{Cell death detection by Acridine Orange and Ethidium bromide method}

The detection of green and orange stained chromatin cells fairly unequivocally demonstrates the presence of early and late apoptotic cells respectively. Also, the significantly higher values obtained for the positive control served to validate our experimental methodology. Our findings are the first of its kind, wherein we have demonstrated arecoline-mediated cell death in a concentration-dependent manner, based on our fluorescent microscope images (Figure 3) as well as the graphical representation (Figure 4) of cytotoxicity data for arecoline-treated $\mathrm{NIH} / 3 \mathrm{~T} 3$ cells.

\section{Cell Cycle Analysis by Flow Cytometry}

Arecoline is known to suppress the growth of several cells, including those of epithelial origin. ${ }^{32}$ However, the exact mechanism is still unknown. The growth of all the mammalian cells is tightly regulated by cell cycle control and normally CDK1 and CDK2 controls the checkpoints of both G1 and G2M phase. Cyclin B1 activates CDK1 and p21 and p27 inhibits the function of $\mathrm{CDK}^{33}$ Exposure of Oral Mucosal Fibroblasts (OMF) to a concentration greater than $200 \mu \mathrm{M}$ resulted in a the $\mathrm{G} 2 / \mathrm{M}$ phase block in the cell-cycle. ${ }^{34}$ However, this type of arrest may be cell-specific and/or arecoline concentration-dependent. For e.g., in normal rat hepatocytes treated with arecoline, there was a G0/ G1 arrest, ${ }^{19}$ while there was a $\mathrm{G} 2 / \mathrm{M}$ arrest in Human Umbilical Vein Endothelial Cells ${ }^{35}$ (HUVEC cells).

Table 3: Protection-Challenge Experiments were done on NIH/3T3 cells and the MTT assay was performed. This table provides cytotoxicity data following exposure of NIH/3T3 cells to the different combinations of drugs/chemicals. The experimental design is explained in the methods section. A marginal cytoprotective effect was observed in the case of MTT-based cytotoxicity results for both Hesperidin and TFP.

\begin{tabular}{|c|c|c|c|c|c|}
\hline S.No & Sample & Day1 & Day2 & \%of Live & \%of Dead \\
\hline 1 & Positive control & $0.5 \mu \mathrm{M}$ Doxo & $0.5 \mu \mathrm{M}$ Doxo & 79.58 & 20.42 \\
\hline 2 & Vehicle control & $0.01 \%$ DMSO & $0.01 \%$ DMSO & 98.98 & 1.02 \\
\hline 3 & Negative control & No drug & No drug & 99.63 & 0.37 \\
\hline 4 & Hesperidin $\mathrm{IC}_{25}+$ Hesperidin $\mathrm{IC}_{25}$ & Hesperidin $\mathrm{IC}_{25}$ & Hesperidin $\mathrm{IC}_{25}$ & 93.66 & 6.34 \\
\hline 5 & Hesperidin $\mathrm{IC}_{25}+$ TFP-IC $\mathrm{C}_{25}$ & Hesperidin $\mathrm{IC}_{25}$ & TFP-IC 25 & 95.20 & 4.80 \\
\hline 6 & Hesperidin $\mathrm{IC}_{25}+$ Arecoline $\mathrm{IC}_{50}$ & Hesperidin $\mathrm{IC}_{25}$ & Arecoline $\mathrm{IC}_{50}$ & 95.94 & 4.06 \\
\hline
\end{tabular}

Table 4: Protection-Challenge Experiments were done on NIH/3T3 cells and the flow cytometry assay was performed. This table provides Pl-based flow cytometry data following exposure of NIH/3T3 cells to the different combinations of drugs/chemicals. The experimental design is explained in the methods section. A marginal cytoprotective effect was observed in the case of PI-based cell death data for both Hesperidin and TFP.

\begin{tabular}{|c|c|c|c|c|}
\hline S.No & Sample & Day1 & Day2 & \%of Cytotoxicity \\
\hline 1 & Positive control & $0.5 \mu \mathrm{M}$ Doxo & $0.5 \mu \mathrm{M}$ Doxo & 39.35 \\
\hline 2 & Vehicle control & $0.01 \%$ DMSO & $0.01 \%$ DMSO & 1.05 \\
\hline 3 & Negative control & No drug & No drug & 0.6 \\
\hline 4 & Hesperidin $\mathrm{IC}_{25}+$ Hesperidin $\mathrm{IC}_{25}$ & Hesperidin $\mathrm{IC}_{25}$ & Hesperidin $\mathrm{IC}_{25}$ & 6.1 \\
\hline 5 & Hesperidin $\mathrm{IC}_{25}+$ TFP-IC $\mathrm{I}_{25}$ & Hesperidin $\mathrm{IC}_{25}$ & TFP-IC 25 & 4.4 \\
\hline 6 & Hesperidin $\mathrm{IC}_{25}+$ Arecoline $\mathrm{IC}_{50}$ & Hesperidin $\mathrm{IC}_{25}$ & Arecoline $\mathrm{IC}_{50}$ & 4.1 \\
\hline
\end{tabular}




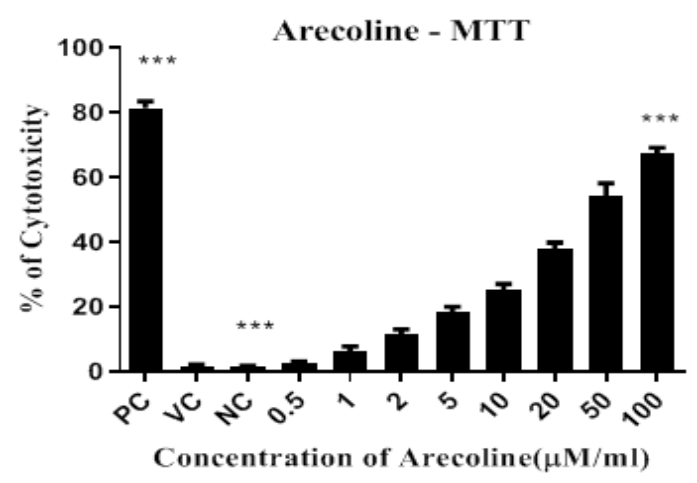

Figure 1: Cytotoxic effect of Arecoline on NIH 3T3 Fibroblasts. Cells were exposed to Arecoline $(0-100 \mu \mathrm{M})$ for 24 hr. Cytotoxicity was measured with MTT assay. - *II denotes

significance with respect to positive, negative and DMSO controls. ${ }^{* \star *} p<0.001$ calculated using one-way ANOVA Mean \pm SEM, $n=3$ ).

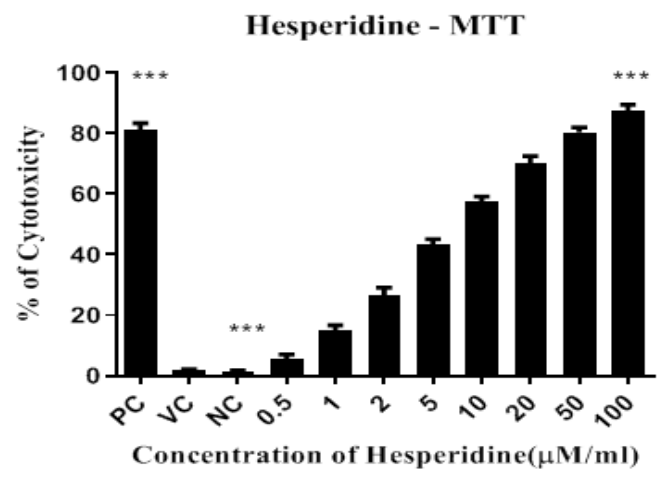

Figure 2: Cytotoxic effect of Hesperidin on NIH/3T3 Fibroblasts. Cells were exposed to Arecoline $(0-100 \mu \mathrm{M})$ for 24 hr. Cytotoxicity was measured with MTT assay. - *II denotes significance with respect to positive, negative and DMSO controls. ${ }^{* *} p<0.001$ calculated using one-way ANOVA (Mean \pm SEM, $n=3$ ).

Another paper has documented no alterations in the percentage of arecoline-treated Hel fibroblast cells in the different phases. ${ }^{36}$ Despite similarities in doxorubinmediated G2/M arrest (as reported in our study) (Figure 5), plausible cell-specific variations in cell cycle data, has made data extrapolation a challenging endeavor. ${ }^{37}$ These variations in the results in terms of the cells getting arrested at various phases of the cell cycle, provides an impetus for a more thorough investigation into the possible links between cell cycle arrest and cell death. This correlation should be done using a battery of markers including the cellular redox status in a cellbased model that is a good surrogate for normal and diseased fibroblasts.

\section{Live and dead cell Analysis using Propidium lodide by Flow Cytometry}

Our results have shown that arecoline has caused a dose-dependent increase in cell death (Figure 6). This

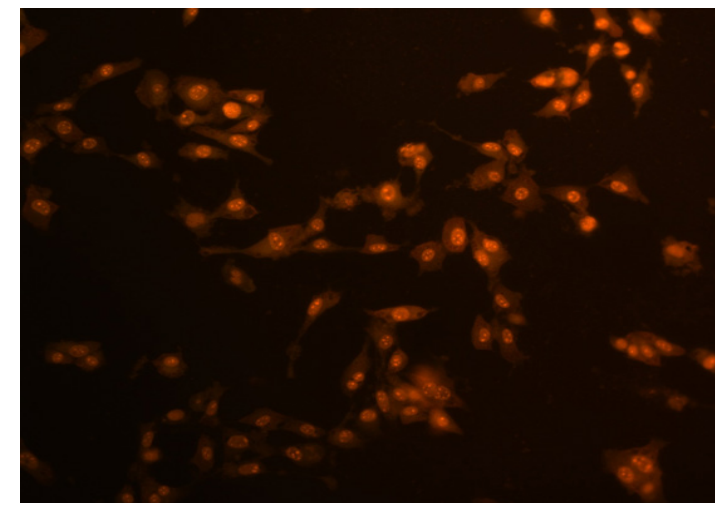

Figure 3A: Cell Death Detection by Acridine Orange and Ethidium Bromide method. a) Positive Control (late apoptotic cells - arrow marked).

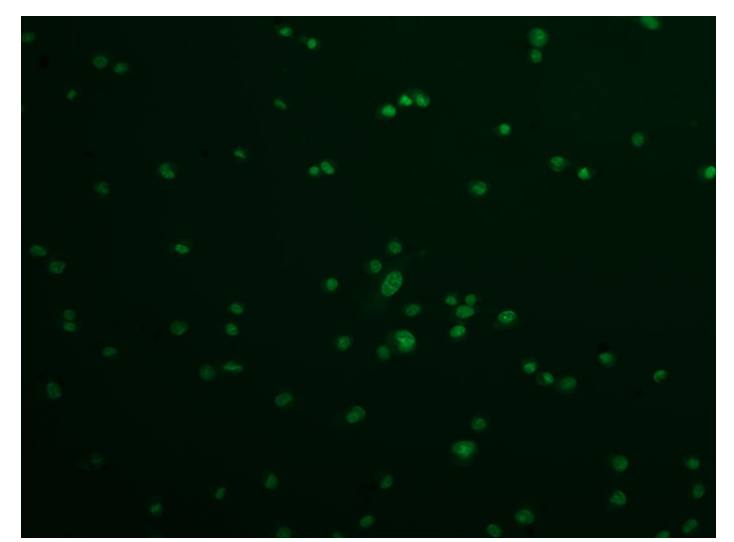

Figure 3B: Cell Death Detection by Acridine Orange and Ethidium Bromide method. b) Vehicle Control.

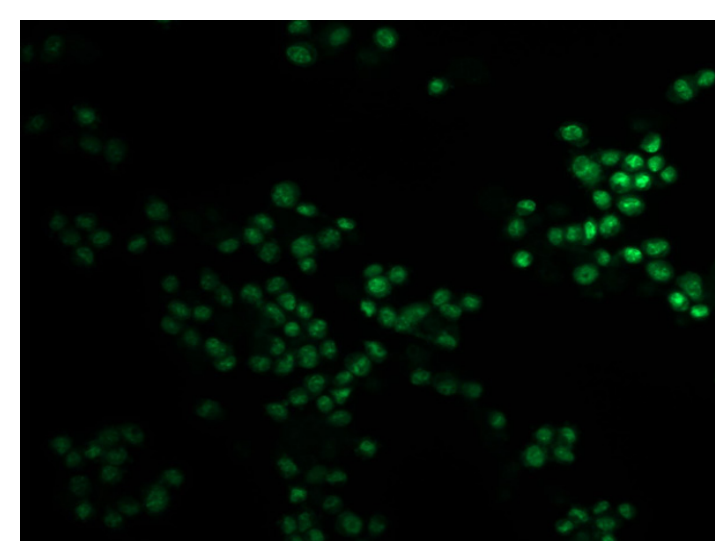

Figure 3C: Cell Death Detection by Acridine Orange and Ethidium Bromide method. c) Negative Control.

type of cell-specific analysis is important, since certain fibroblasts (for e.g., Hel fibroblasts) are relatively resistant to arecoline-mediated toxicity, unlike the higher percentage of cell death in arecoline-treated $\mathrm{HaCaT}$ cells. $^{36}$

\section{Intracellular ROS Detection by DCFDA Method}

We found that arecoline induces a dose-dependent increase in ROS in NIH/3T3 cells and these results are 


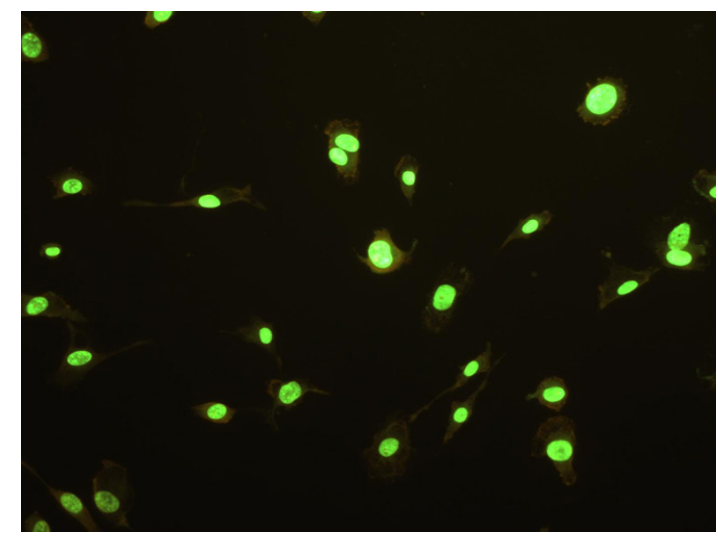

Figure 3D: Cell Death Detection by Acridine Orange and Ethidium Bromide method. d) Arecoline 19 $\mu \mathrm{M}$.

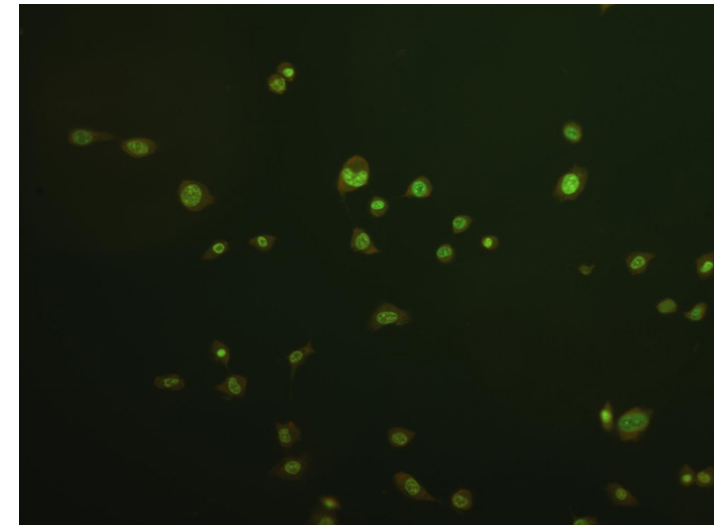

Figure 3E: Cell Death Detection by Acridine Orange and Ethidium Bromide method. e) Arecoline $38 \mu \mathrm{M}$.

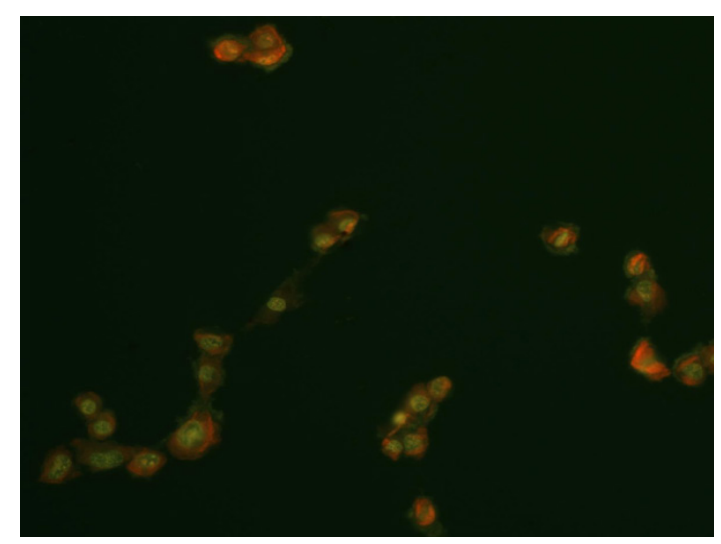

Figure 3F: Cell Death Detection by Acridine Orange and Ethidium Bromide method. f) Arecoline $76 \mu \mathrm{M}$.

similar to those reported by others, despite variations in the experimental conditions (Figure 7). It has been reported that Arecoline induces ROS production significantly in a dose-dependent manner in 3T3-L1 pre-adipocytes. ${ }^{27}$ Another paper has provided evidence for arecoline increasing mitochondrial-derived ROS in human buccal mucosal fibroblasts. ${ }^{38}$ Arecoline treatment showed increased ROS production than the vehicle and

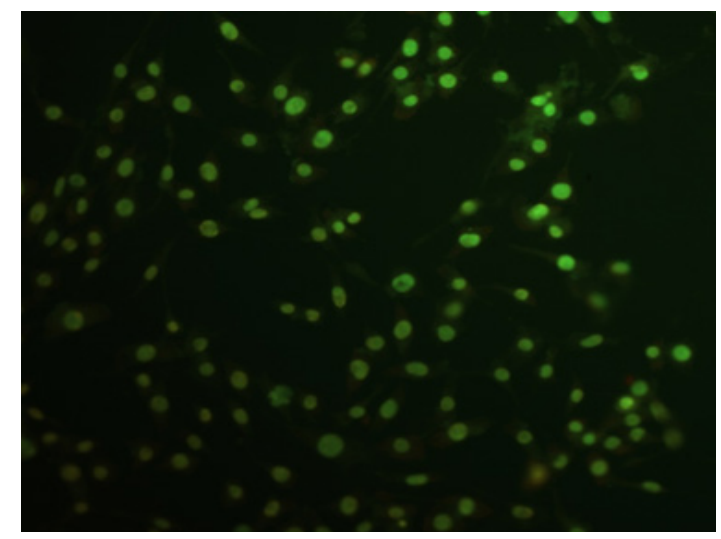

Figure 3G: Cell Death Detection by Acridine Orange and Ethidium Bromide method. g) Hesperidin $3.75 \mu \mathrm{M}$.

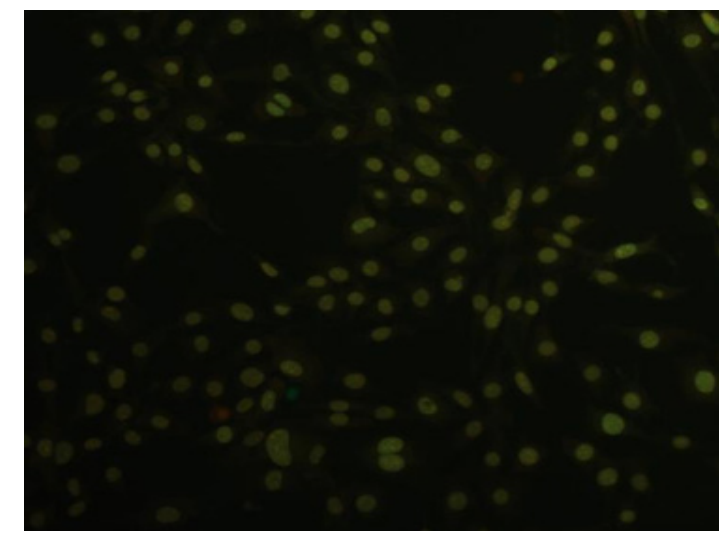

Figure 3H: Cell Death Detection by Acridine Orange and Ethidium Bromide method. h) Hesperidin 7.5 $\mu \mathrm{M}$.

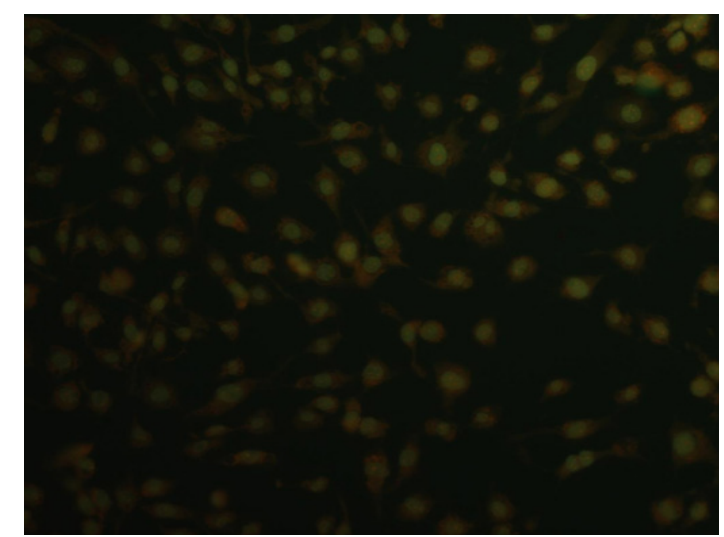

Figure 3I: Cell Death Detection by Acridine Orange and Ethidium Bromide method. i) Hesperidin $15 \mu \mathrm{M}$.

negative control. Positive control showed significantly increased ROS generation.

\section{Cell Cycle Analysis of Hesperidin}

Our data provides evidence for the dose as the major determinant for the phase at which the cells are arrested (Figure 8). It is fairly well established that the cell line-specific dose and exposure conditions need to be 
Apoptosis detection by Ao/EtBr Method

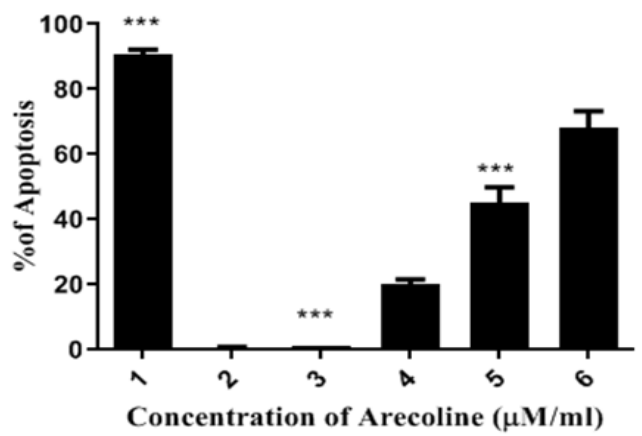

Figure 4A: Cell Death Detection by Acridine Orange and Ethidium Bromide method (graphical Representation)1) Positive Control 2) Vehicle Control 3) Negative Control 4) Arecoline $19 \mu \mathrm{M}$ 5)Arecoline $38 \mu \mathrm{M}$ 6) Arecoline $76 \mu \mathrm{M}-{ }^{*} \|$ denotes significance with respect to positive, negative and DMSO controls. ${ }^{* * *} p<0.001$ calculated using one-way ANOVA (mean $\pm S E M, n=2)$.

\section{Apoptosis detection by Ao/EtBr Method}

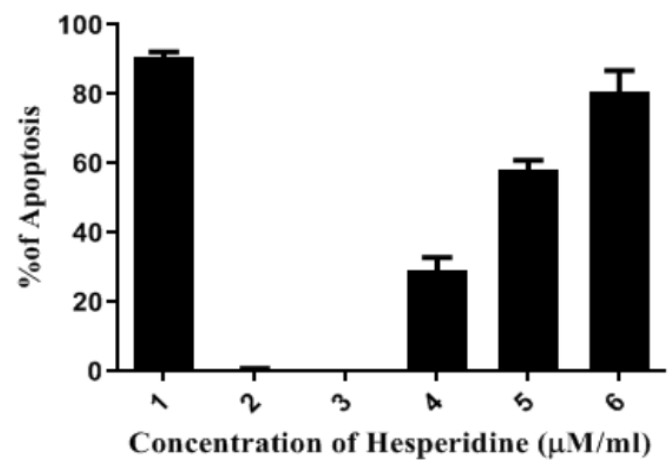

Figure 4B: Cell Death Detection by Acridine Orange and Ethidium Bromide method (graphical Representation)1) Positive Control 2) Vehicle Control 3) Negative Control 4) Hesperidin 3.5 $\mu \mathrm{M}$ 5)Hesperidin $7.5 \mu \mathrm{M}$ 6) Hesperidin $15 \mu \mathrm{M}$

optimized for the demonstration of cytostatic effects due to cell cycle perturbations as opposed to cell death, possibly due to alterations in the ratios of pro and anti-apoptotic molecules. ${ }^{39}$ This finding corroborates that of another research group's results in terms of Doxorubicin-treated 3T3 cells blocked in the same phase of the cell cycle, despite concentration-related differences $^{40}(\sim 0.345 \mu$ moles $/ \mathrm{ml})$. A similar type of G2/M growth arrest was demonstrated in doxorubicintreated $\mathrm{Ba} / \mathrm{F} 3$ and EL4 lymphoid cells. ${ }^{41}$ This type of a $\mathrm{G} 2 / \mathrm{M}$ phase arrest has also been demonstrated in Hesperidin-treated gall bladder carcinoma cells. ${ }^{42}$ Further, it has been reported that Hesperidin can cause certain cancerous cells to be arrested in the G0/G1 stage. $^{43}$ The absence of a G0/G1 peak in our study may be attributable to concentration or cell line-specific variations including the redox status of the cell. Also,
Cell Cycle Analysis - Arecoline

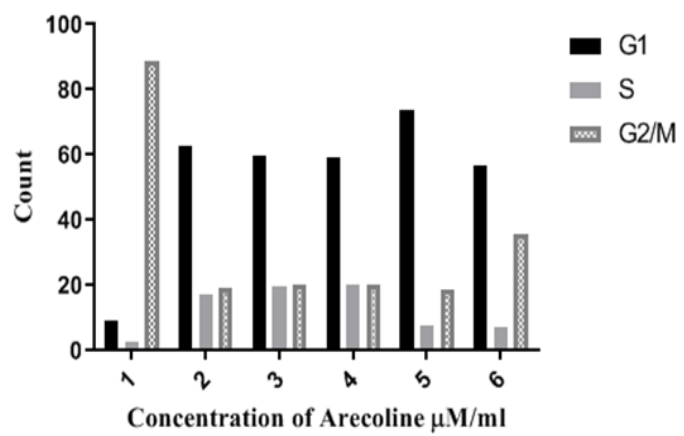

Figure 5: Cell Cycle Analysis of Arecoline: 1) Positive Control 2) Vehicle Control 3) Negative Control 4) Arecoline 19 $\mu \mathrm{M}$ 5) Arecoline $38 \mu \mathrm{M}$ 6) Arecoline $76 \mu \mathrm{M}(\mathrm{n}=1)$.

Live \& Dead Cell Analysis by Flow Cytometry

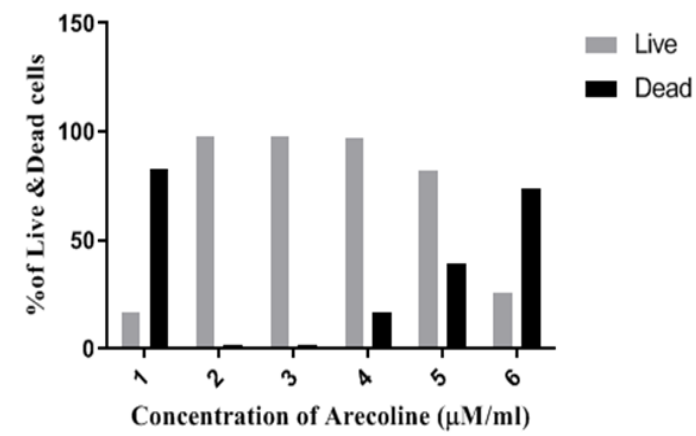

Figure 6: Live and Dead cell Analysis using Propidium lodide by Flow Cytometry: 1) Positive Control 2) Vehicle Control 3) Negative Control 4) Arecoline $19 \mu \mathrm{M}$ 5) Arecoline $38 \mu \mathrm{M}$ 6) Arecoline $76 \mu \mathrm{M}(n=1)$.

the amount of ROS generated (at the concentrations tested) may be an important and pivotal determinant in promoting survival of the NIH/3T3 cells. This provides a basis for testing the pro-survival capability over a wide range of concentrations. Also, these encouraging results pave the way for evaluating combination treatments with other natural molecules in normal as well as in cancerous cell lines.

\section{Live and dead cell Analysis using Propidium lodide by Flow Cytometry}

Hesperidin is a known to have cytostatic and cytotoxic effects on various cancer models with elevated amounts of $\mathrm{p} 53$, inhibitors of the cyclin-dependent kinases and decreased levels of cyclins and cyclin-dependent kinases. It also alters the expression levels of pro/antiapoptotic proteins and activates caspases. Hesperidin also induces apoptosis by activating JNK pathway and caspase-3 independent cell death. ${ }^{39}$ Our data (Figure 9). is consistent with a concentration-dependent increase in 


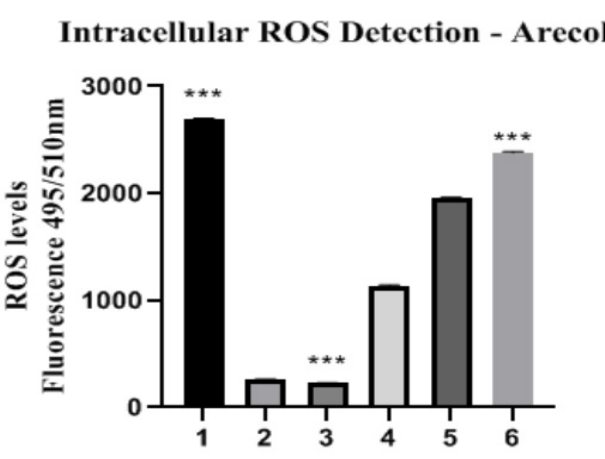

Concentration of Arecoline $(\mu \mathrm{M} / \mathrm{ml})$

Figure 7: Intracellular ROS Detection by DCFDA Method: 1) Positive Control 2) Vehicle Control 3) Negative Control 4) Arecoline $19 \mu \mathrm{M}$ 5) Arecoline $38 \mu \mathrm{M}$ 6) Arecoline $76 \mu \mathrm{M}-*$ II denotes significance with respect to positive, negative and DMSO controls. ${ }^{* * *} p<0.001$ calculated using one-way ANOVA (Mean \pm SEM, $n=2)$.

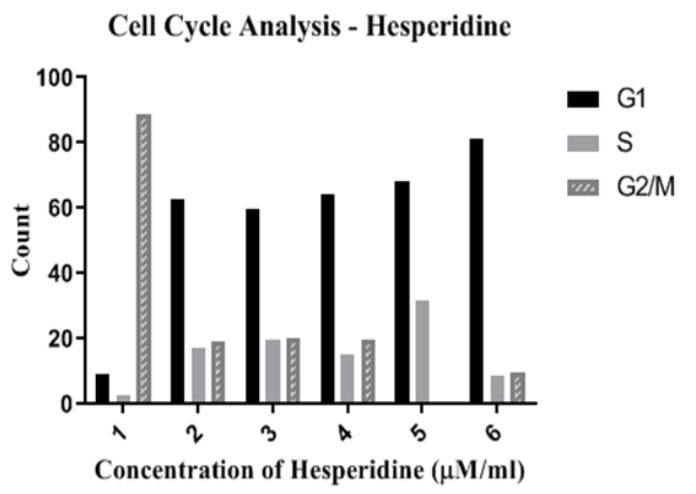

Figure 8: Cell Cycle Analysis of Hesperidin: 1) Positive Control 2) Vehicle Control 3) Negative Control 4) Hesperidin

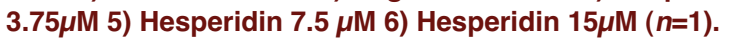

Live and Dead Analysis - Hesperidine

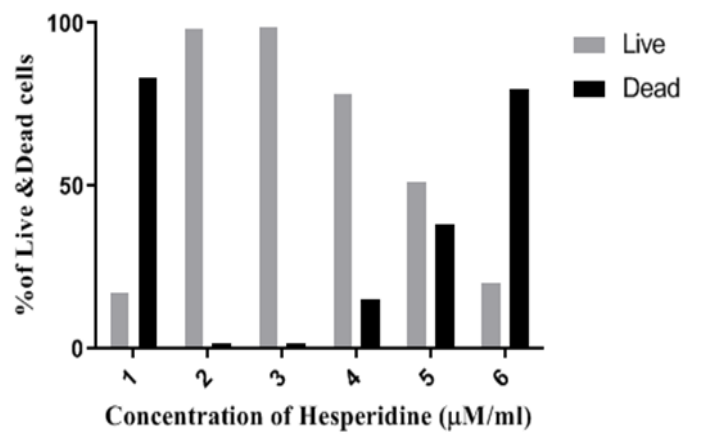

Figure 9: Live and dead cell Analysis of Hesperidin using Propidium lodide by Flow Cytometry:1) Positive Control 2) Vehicle Control 3) Negative Control 4) Hesperidin 3.75 $\mu \mathrm{M}$ 5) Hesperidin7.5 $\mu \mathrm{M}$ 6) Hesperidin $15 \mu \mathrm{M}(\mathrm{n}=1)$
Intracellular ROS Detection - Hesperidine

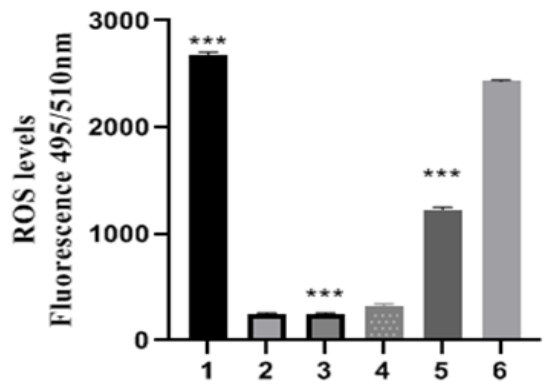

Concentration of Hesperidine $(\mu \mathrm{M} / \mathrm{ml})$

Figure 10: Intracellular ROS Detection by DCFDA Method: 1) Positive Control 2) Vehicle Control 3) Negative Control 4) Hesperidin $3.75 \mu \mathrm{M} / \mathrm{ml}$ 5) Hesperidin $7.5 \mu \mathrm{M}$ 6) Hesperidin $15 \mu \mathrm{M} / \mathrm{ml}-{ }^{*} \mid l$ denotes significance with respect to positive, negative and DMSO controls. ${ }^{* * *} p<0.001$ calculated using one-way ANOVA (Mean \pm SEM, $n=2$ ).

Trifluoperazine - MTT

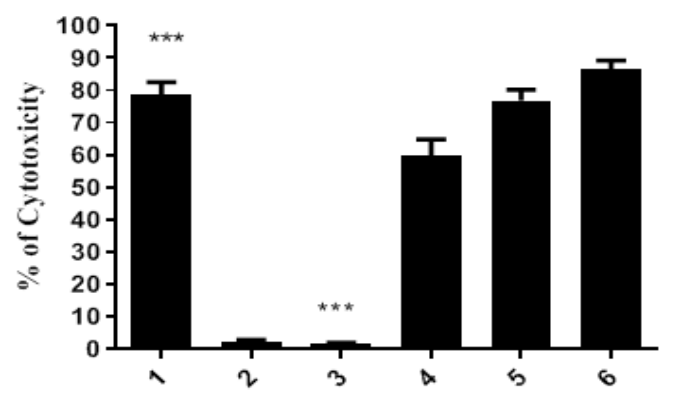

Concentration of Trifluoperazine $(\mu \mathrm{M} / \mathrm{ml})$

Figure 11: Cytotoxic effect of Trifluoperazine (TFP) on NIH/3T3 Fibroblasts. 1) Positive Control 2) Vehicle Control 3) Negative Control 4) 2.5 $\mu \mathrm{M}$ TFP 5) $5 \mu \mathrm{M}$ TFP 6) $10 \mu \mathrm{M}$ TFP Cells were exposed to Trifluoperazine $(0-10 \mu \mathrm{M})$ for $24 \mathrm{hr}$. Cytotoxicity was measured with MTT assay. $-{ }^{*}$ II denotes significance with respect to positive, negative and DMSO controls. ${ }^{* * *} p<0.001$ calculated using one-way ANOVA (Mean \pm SEM, $n=3$ ).

cell death with apoptosis (chemical stress-induced form of cell demise) as the probable mechanism.

\section{Intracellular Hesperidin-mediated ROS production (DCFH-DA assay)}

It has been shown by other researchers that hesperidin inhibited ROS production in 3T3-L1 cells. ${ }^{44}$ An earlier report has documented protection against free radicalmediated radiation injury in a herbal extract, which has hesperidin as its important bioactive component. ${ }^{45}$ Our data is consistent with a similar concentrationdependent inhibition of ROS production in NIH/3T3 cells (Figure $10 \mathrm{~N}=2$ ). Hence, our experimental design, involving a challenge and protection/protection and 
challenge fits in with the plausible role of Hesperidin for altering ROS levels. Another report specifically showed that pre-treatment with hesperidin was involved in peroxynitrite radical scavenging in fibroblasts. This antioxidant mechanism, in part, may be involved in Hesperidin-mediated cytoprotection. This mechanism would be expected to be one of the key determinants for cell survival versus cell death. ${ }^{46}$ However, it should be noted that Hesperidin-mediated cytotoxic effects may also involve other mechanisms as well, since this natural molecule has been shown to enhance the toxicity of doxorubicin, independent of oxidative damage. However, this result was obtained in HepG2 cells and cell line specific variations cannot be ruled out. ${ }^{47}$

\section{Cytotoxic effect of Trifluoperazine (TFP) on $\mathrm{NIH} / 3 \mathrm{~T} 3$ fibroblasts}

The rationale behind the use of Trifluoperazine is due to it being using as a selective antagonist of S100A4. Also, as a drug repurposing strategy, research has shown that the antipsychotic agent is capable of inhibiting the invasiveness of certain cancer cells. ${ }^{48}$ It has been shown that TFP can inhibit cell growth in HT1080 fibrosarcoma cells by inducing the early growth response gene's (Egr-1) expression. ${ }^{49}$ Also, TFP has shown potential as an adjuvant in restoring Adriamycin sensitivity to apoptosis in certain leukemic cancer cells. This mechanism was attributed to be due to the downregulation of the expression of P-glycoprotein. ${ }^{50}$ In pancreatic ductal carcinoma cells, it has been shown that TFP-mediated apoptosis is associated with an increased production of ROS. ${ }^{51}$

There is some evidence in the literature to show that TFP has a protective role against $\mathrm{H}_{2} \mathrm{O}_{2}$ mediated apoptosis in PC12 cells. ${ }^{52}$ It can inhibit the ROS and reduce the cell death (Apoptosis) by increasing the mitochondrial membrane potential (MMP). These apparently paradoxical results prompted us to evaluate the role of this S100A4 antagonist in protection-challenge and challenge-protection experiments. In order to determine the appropriate dose for these experiments, cytotoxicity experiments were performed (Figure 11). This reproducible demonstration of the $\mathrm{IC}_{50}$ value $(2.2$ Micromolar) also served to validate our methodology.

\section{MTT Challenge and Protection Assay}

Our results have shown that TFP may improve the relative survival of $\mathrm{NIH} / 3 \mathrm{~T} 3$ cells in comparison with that of Hesperidin (Table 1 -Sl. No.6 versus 7; Sl. No. 8 versus $9 ; \mathrm{N}=2$ ). Many plant compounds possess various biological activities and thus protects the cell from various damage. These plant compounds are known to scavenge the ROS and guard the cell; Hesperidin is one among those which is proved to scavenge the ROS, ${ }^{53}$ even though it is concentration, cell line and cell density dependent apart from the role of redox-sensitive molecules and enzyme systems. Hence, our encouraging findings will provide an impetus to further examine the extent and basis for the observed, relative improvements in survival.

\section{Live and Dead Analysis using Flow-Cytometry (Challenge and Protection Assay)}

It is known that arecoline depletes glutathione (GSH) levels $^{24}$ and thiol levels in various model systems. Hesperidin was able to alleviate the trichloroethyleneinduced oxidative stress in D. melanogaster as well as it could protect the experimentally induced kidney damage in diabetic rats $^{54}$ by reducing superoxide dismutase; glutathione and catalase levels and our results are consistent with this above results. Pre-treatment with NAC, antagonized the $24 \mathrm{hr}$ of arecoline effects on cell cycle control proteins such as CDK1, p21 and p27 and induces cyclin B1 and $\mathrm{p} 53 .{ }^{27}$ In the context of related information in the literature and our results (Table 4 Sl. No.6 versus 7; Sl. No. 8 versus 9 in both tables; $N=1$ ), it can be inferred that decreased effect of arecoline on $\mathrm{NIH} / 3 \mathrm{~T} 3$ fibroblasts cell viability depends on a pathway which requires ROS induction.

\section{MTT and Flow Cytometry Data: Protection and Challenge}

Our results seem to indicate some change in the survival of cells, with arecoline have a marginally higher cytoprotective property (Table 2 and 3 -comparison of Sl. No. 5 versus 6 in both tables; $\mathrm{N}=2$ )). However, more work needs to be done to further evaluate these findings. Specifically, the role of detoxifying enzymes and clearance-related mechanisms must be taken into account (in the in vivo context). However, this validated design can be used to test these chemicals in other cell lines including those that represent normal and fibrotic buccal mucosal fibroblasts as well those that represent cancers of different sites in humans. This approach will be to ensure that the results are evaluated in a better manner for safety assessment purposes.

\section{CONCLUSION}

Safety assessment of cytotoxic chemicals as well as chemotherapeutic/chemo-preventive natural molecules is an important aspect in toxicity evaluation and in drug development. We have showed the relative cytotoxicity and cell death potential of arecoline and hesperidinemediated cell death. Also, the protective effect of 
Hesperidine and Trifluoperazine (anti-S100A4) against arecoline-mediated cell death was shown with the latter being relatively better (under our defined experimental conditions). Hence, our findings substantiate the need to thoroughly assess the observed protective mechanisms in suitable model systems, especially those in which arecoline has been attributed to be the principal etiologic agent. This approach will extend our safety study to determining the efficacy of the two molecules (Hesperidin and Trifluoperazine).

\section{ACKNOWLEDGEMENT}

The authors thank the management of VIT for their constant encouragement and support and also for creating the scientific ambience. The corresponding author also thanks the other research scholars as well as the short-term project students for their support.

\section{CONFLICT OF INTEREST}

The authors declare no conflict of interests.

\section{ABBREVIATIONS}

NIH/3T3: National Institute of Health/3-day transfer, inoculum $3 \times 105$ cells; OSF: Oral Submucous Fibrosis; DMSO: Dimethyl Sulfoxide; MTT: 3-(4,5-dimethylthiazol-2-yl)-2,5-diphenyltetrazolium bromide; AO/EtBr: Acridine Orange/Ethidium Bromide; PI: Propidium Iodide; DCFH-DA: 2'-7'dichlorofluorescin diacetate; ROS: Reactive Oxygen Species; S100A4: S100 calcium-binding protein A4; IC $_{50}$ : half maximal inhibitory concentration; TGF- $\beta$ : Transforming Growth Factor-beta; MMP-2: Matrix Metalloproteinase-2; FBS: Fetal Bovine Serum; PBS: Phosphate Buffered Saline; NAD (P)H: Reduced form of Nicotinamide Adenine Dinucleotide Phosphate; RIPA: Radioimmunoprecipitation assay; 3T3-L1: cell line derived from (mouse) 3T3 cells; CDK1: cyclindependent kinase1; CDK2: cyclin-dependent kinase2; p21/p27: cyclin-dependent kinase inhibitors; Ba/F3: a murine interleukin-3 dependent pro-B cell line; EL4: murine Lymphoblast cell line; JNK: c-Jun N-terminal kinase; HepG2: a human liver cancer cell line; HT1080: Human fibrosarcoma Cell Line.

\section{REFERENCES}

1. Sundqvist K, Liu Y, Nair J, Bartsch H, Arvidson K, Grafström RC. Cytotoxic and genotoxic effects of areca nut-related compounds in cultured human buccal epithelial cells. Cancer Research. 1989;49(19):5294-8.

2. Huang LW, Hsieh BS, Cheng HL, Hu YC, Chang WT, Chang KL. Arecoline decreases interleukin- 6 production and induces apoptosis and cell cycle arrest in human basal cell carcinoma cells. Toxicology and Applied Pharmacology. 2012; 258(2):199-207.

3. Tsai YS, Lee KW, Huang JL, Liu YS, Juo SH, Kuo WR, et al. Arecoline, a major alkaloid of areca nut, inhibits p53, represses DNA repair and triggers DNA damage response in human epithelial cells. Toxicology. 2008;249(23):230-7.

4. Huang JL, Lu HH, Lu YN, Hung PS, Lin YJ, Lin CC, et al. Enhancement of the genotoxicity of benzo [a] pyrene by arecoline through suppression of DNA repair in HEp-2 cells. Toxicology in vitro. 2016;33:80-7.

5. Panigrahi GB, Rao AR. Chromosome-breaking ability of arecoline, a major betel-nut alkaloid, in mouse bone-marrow cells in vivo. Mutation Research Letters. 1982; 103(2):197-204.

6. Kuo TM, Luo SY, Chiang SL, Yeh KT, Hsu HT, Wu CT. Fibrotic effects of arecoline $\mathrm{N}$-oxide in oral potentially malignant disorders. Journal of Agricultural and Food Chemistry. 2015;63(24):5787-94

7. Ambartsumian N, Klingelhöfer J, Grigorian M. The Multifaceted S100A4 Protein in Cancer and Inflammation. Methods Mol Biol. 2019;1929:339-65.

8. Yu CC, Tsai $\mathrm{CH}$, Hsu HI, Chang YC. Elevation of S100A4 expression in buccal mucosal fibroblasts by arecoline: Involvement in the pathogenesis of oral sub mucous fibrosis. PLoS One. 2013;8(1):e55122.

9. Wilmsen PK, Spada DS, Salvador M. Antioxidant activity of the flavonoid hesperidin in chemical and biological systems. J Agric Food Chem. 2005; 53(12):4757-61.

10. Nijveldt RJ, VanNood E, VanHoorn DE, Boelens PG, VanNorren K, VanLeeuwen PA. Flavonoids: A review of probable mechanisms of action and potential applications. Am J Clin Nutr. 2001;74(4):418-25.

11. Cincin ZB, Unlu M, Kiran B, Bireller ES, Baran Y, Cakmakoglu B. Antiproliferative, apoptotic and signal transduction effects of hesperidin in nonsmall cell lung cancer cells. Cellular Oncology. 2015;38(3):195-204.

12. Agar OT, Dikmen M, Ozturk N, Yilmaz MA, Temel H, Turkmenoglu FP. Comparative Studies on Phenolic Composition, Antioxidant, Wound Healing and Cytotoxic Activities of Selected Achillea L. Species Growing in Turkey. Molecules. 2015;20(10):17976-8000.

13. Meng C, Guo Z, Li D, Li H, He J, Wen D, et al. "Preventive effect of hesperidin modulates inflammatory responses and antioxidant status following acute myocardial infarction through the expression of PPARy and $\mathrm{Bcl} 2$ in model mice". Molecular Medicine Reports. 2018;17(1):1261-8.

14. Todaro GJ, Green H. Quantitative studies of the growth of mouse embryo cells in culture and their development into established lines. J Cell Biol. 1963;17(2):299-313.

15. Gasque KC, Da S, Al-Ahj LP, Oliveira RC, Magalhães AC. Cell density and solvent are critical parameters affecting formazan evaluation in MTT assay. Brazilian Archives of Biology and Technology. 2014;57(3):381-5.

16. Shih Y, See P, Wu C, Tseng Y, Wu Y, Lo Y. Free Radical Biology and Medicine Arecoline, a major alkaloid of the areca nut, causes neurotoxicity through enhancement of oxidative stress and suppression of the antioxidant protective system. Free Radical Biology and Medicine. 2010;49(10):1471-9.

17. Kasibhatla S, Amarante-Mendes GP, Finucane D, Brunner T, Bossy-Wetzel E, Green DR. Acridine orange/ethidium bromide (AO/EB) staining to detect apoptosis. Cold Spring Harbor Protocols. 2006;2006(3):pdb-rot4493.

18. Pozarowski P, Darzynkiewicz Z. Analysis of Cell Cycle by Flow Cytometry. (eds) Checkpoint Controls and Cancer. Methods in Molecular Biology. Totowa, NJ, Humana Press. 2004;281:301-11.

19. Chang MC, Ho YS, Lee PH, Chan CP, Lee JJ, Hahn LJ. Areca nut extract and arecoline induced the cell cycle arrest but not apoptosis of cultured oral KB epithelial cells: Association of glutathione, reactive oxygen species and mitochondrial membrane potential. Carcinogenesis. 2001b;22(9):1527-35.

20. Schmid I, Ferbas J, Uittenbogaart CH, Giorgi JV. Flow cytometric analysis of live cell proliferation and phenotype in populations with low viability. Cytometry: The Journal of the International Society for Analytical Cytology. 1999;35(1):64-74.

21. Onodera Y, Teramura T, Takehara T, Obora K, Mori T, Fukuda K. miR-155 induces ROS generation through downregulation of antioxidation-related genes in mesenchymal stem cells. Aging Cell. 2017;16(6):1369-80.

22. Ferrer E, Juan-García A, Font G, Ruiz MJ. Reactive oxygen species induced by beauvericin, patulin and zearalenone in $\mathrm{CHO}-\mathrm{K} 1$ cells. Toxicology in vitro. 2009; 23(8):1504-9. 
23. Tsai CL, Kuo MY, Hahn LJ, Kuo YS, Yang PJ, Jeng JH. Cytotoxic and cytostatic effects of arecoline on oral mucosal fibroblasts. Proceedings of the National Science Council, Republic of China. Part B, Life Sciences. 1997;21(4):161-7.

24. Jeng JH, Tsai CL, Hahn LJ, Yang PJ, Kuo YS, Kuo MY. Arecoline cytotoxicity on human oral mucosal fibroblasts related to cellular thiol and esterase activities. Food Chem Toxicol. 1999;37(7):751-6.

25. Chang YC, Hu CC, Lii CK, Tai KW, Yang SH, Chou MY. Cytotoxicity and arecoline mechanisms in human gingival fibroblasts in vitro. Clin Oral Investig. 2001;5(1):51-6.

26. Ling HY, He J, Yang SS, Zhang KF, He JQ, Zhu ZM, et al. The effects of arecoline on the lipid metabolism of 3T3-L1 adipocytes. Zhongguo ying yong sheng li xue za zhi= Zhongguo yingyong shenglixue zazhi. Chinese Journal of Applied Physiology. 2017;33(1):22-5.

27. Tian ZH, Weng JT, Shih LJ, Siao AC, Chan TY, Tsuei YW, et al. Arecoline inhibits the growth of 3T3-L1 preadipocytes via AMP-activated protein kinase and reactive oxygen species pathways. PLoS ONE. 2018;13:6-9.

28. Barreca D, Bellocco E, Caristi C, Leuzzi U, Gattuso G. Flavonoid profile and radical-scavenging activity of Mediterranean sweet lemon (Citrus limetta Risso) juice. Food Chemistry. 2011;129(2):417-22.

29. Galati EM, Monforte MT, Kirjavainen S, Forestieri AM, Trovato A, Tripodo MM Biological effects of hesperidin, a citrus flavonoid.(Note I): Antiinflammatory and analgesic activity. Farmaco (Societa Chimica Italiana: 1989). 1994;40(11):709-12.

30. Ahmadi A, Shadboorestan A, Nabavi SF, Setzer WN, Nabavi SM. The Role of Hesperidin in Cell Signal Transduction Pathway for the Prevention or Treatment of Cancer. Curr Med Chem. 2015;22(30):3462-71.

31. Kabała-Dzik A, Rzepecka-Stojko A, Kubina R, Iriti M, Wojtyczka RD, Buszman $\mathrm{E}$, et al. Flavonoids, bioactive components of propolis, exhibit cytotoxic activity and induce cell cycle arrest and apoptosis in human breast cancer cells MDA-MB-231 and MCF-7-a comparative study. Cellular and Molecular Biology. 2018;64(8): 1-10.

32. Sundqvist K, Grafström RC. Effects of areca nut on growth, differentiation and formation of DNA damage in cultured human buccal epithelial cells. International Journal of Cancer. 1992;52(2):305-10.

33. Shackelford RE, Kaufmann WK, Paules RS. Oxidative stress and cell cycle checkpoint function. Free Radical Biology and Medicine. 2000;28(9):1387404.

34. Chou WW, Guh JY, Tsai JF, et al. Arecoline-induced growth arrest and p21WAF1 expression are dependent on p53 in rat hepatocytes. Toxicology. 2008;243(1-2):1-10.

35. Kuo FC, Wu DC, Yuan SS, et al. Effects of arecoline in relaxing human umbilical vessels and inhibiting endothelial cell growth. J Perinat Med. 2005;33(5):399-405.

36. Zhou ZS, Li M, Gao F, Peng JY, Xiao HB, Dai LX, et al. Arecoline suppresses $\mathrm{HaCaT}$ cell proliferation through cell cycle regulatory molecules. Oncology Reports. 2013;29(6):2438-44.

37. Kim HS, Lee YS, Kim DK. Doxorubicin exerts cytotoxic effects through cell cycle arrest and Fas-mediated cell death. Pharmacology. 2009;84(5):300-9.

38. Hsieh YP, Wu KJ, Chen HM, Deng YT. Arecoline activates latent transforming growth factor $\beta 1$ via mitochondrial reactive oxygen species in buccal fibroblasts: Suppression by epigallocatechin-3-gallate. J Formos Med Assoc. 2018;117(6):527-34
39. DeOliveira JMPF, Santos C, Fernandes E. Therapeutic potential of hesperidin and its aglycone hesperetin: Cell cycle regulation and apoptosis induction in cancer models. Phytomedicine. 2019;152887.

40. Siu WY, Arooz T, Poon RYC. Differential responses of proliferating versus quiescent cells to adriamycin. Experimental Cell Research. 1999;250(1):13141.

41. Kim HS, Lee YS, Kim DK. Doxorubicin exerts cytotoxic effects through cell cycle arrest and Fas-mediated cell death. Pharmacology. 2009;84(5):300-9.

42. Pandey P, Sayyed U, Tiwari RK, Siddiqui MH, Pathak N, Bajpai P. Hesperidin Induces ROS-Mediated Apoptosis along with Cell Cycle Arrest at G2/M Phase in Human Gall Bladder Carcinoma. Nutrition and Cancer. 2019;71(4):676-87.

43. Xia R, Sheng X, Xu X, Yu C, Lu H. Hesperidin induces apoptosis and G0/ G1 arrest in human non-small cell lung cancer A549 cells. Int J Mol Med. 2018;41(1):464-72.

44. Jeon H, Seo M, Choi H, Lee O, Lee B. Gelidium elegans, an edible red seaweed and hesperidin inhibit lipid accumulation and production of reactive oxygen species and reactive nitrogen species in 3T3-L1 and RAW264. 7 cells. Phytotherapy Research. 2014;28(11):1701-9.

45. Katoch O, Kaushik S, Kumar MSY, Agrawala PK, Misra K. Radioprotective property of an aqueous extract from valeriana wallichii. Journal of Pharmacy and Bioallied Sciences. 2012;4(4):327.

46. Pollard SE, Kuhnle GGC, Vauzour D, Vafeiadou K, Tzounis X, Whiteman M, et al. The reaction of flavonoid metabolites with peroxynitrite. Biochemical and Biophysical Research Communications. 2006;350(4):960-8.

47. Korga A, Ostrowska M, Jozefczyk A, Iwan M, Wojcik R, Zgorka G, et al. Apigenin and hesperidin augment the toxic effect of doxorubicin against HepG2 cells. BMC Pharmacology and Toxicology. 2019;20(1):22.

48. Pulkoski-Gross A, Li J, Zheng C, Li Y, Ouyang N, Rigas B, et al. Repurposing the antipsychotic trifluoperazine as an antimetastasis agent. Mol Pharmacol. 2015;87(3):501-12.

49. Shin SY, Kim SY, Kim JH, Ko J, Kang UG, Kim YS, et al. Induction of early growth response-1 gene expression by calmodulin antagonist trifluoperazine through the activation of Elk-1 in human fibrosarcoma HT1080 cells. Journal of Biological Chemistry. 2001;276(11):7797-805.

50. Shin SY, Choi BH, Kim JR, Kim JH, Lee YH. Suppression of P-glycoprotein expression by antipsychotics trifluoperazine in adriamycin-resistant L1210 mouse leukemia cells. Eur J Pharm Sci. 2006;28(4):300-6.

51. Huang C, Lan W, Fraunhoffer N, Meilerman A, lovanna J, Santofimia-Castaño P. Dissecting the Anticancer Mechanism of Trifluoperazine on Pancreatic Ductal Adenocarcinoma. Cancers. 2019;11(12):1869.

52. Liu S, Han Y, Zhang T, Yang, Z. Protective effect of trifluoperazine on hydrogen peroxide-induced apoptosis in PC12 cells. Brain Research Bulletin. 2011;84(2): 183-8.

53. Estruel-Amades $S$, Massot-Cladera $M$, Garcia-Cerdà $P$, Pérez-Cano FJ, Franch À, Castell $\mathrm{M}$, et al. Protective Effect of Hesperidin on the Oxidative Stress Induced by an Exhausting Exercise in Intensively Trained Rats. Nutrients. 2019;11(4):783.

54. Abolaji AO, Babalola OV, Adegoke AK, Farombi EO. Hesperidin, a citrus bioflavonoid, alleviates trichloroethylene-induced oxidative stress in Drosophila melanogaster. Environmental Toxicology and Pharmacology. 2017;55:202-7.

\section{SUMMARY}

Our experimental design, employing a battery of assays, facilitated the safety (cytotoxicity; ROS induction as well as cell death induction potential) assessment of Hesperidin (a natural molecule with anticancer potential) relative to that of arecoline. Also, our experimental design, involving a challengeprotection-based strategy, enabled us to demonstrate some cytoprotection conferred by Hesperidin as well as Trifluoroperazine (the latter being relatively better). Our results provide us an impetus to adopt this design to test other molecules for assessment of their safety. 


\section{PICTORIAL ABSTRACT}

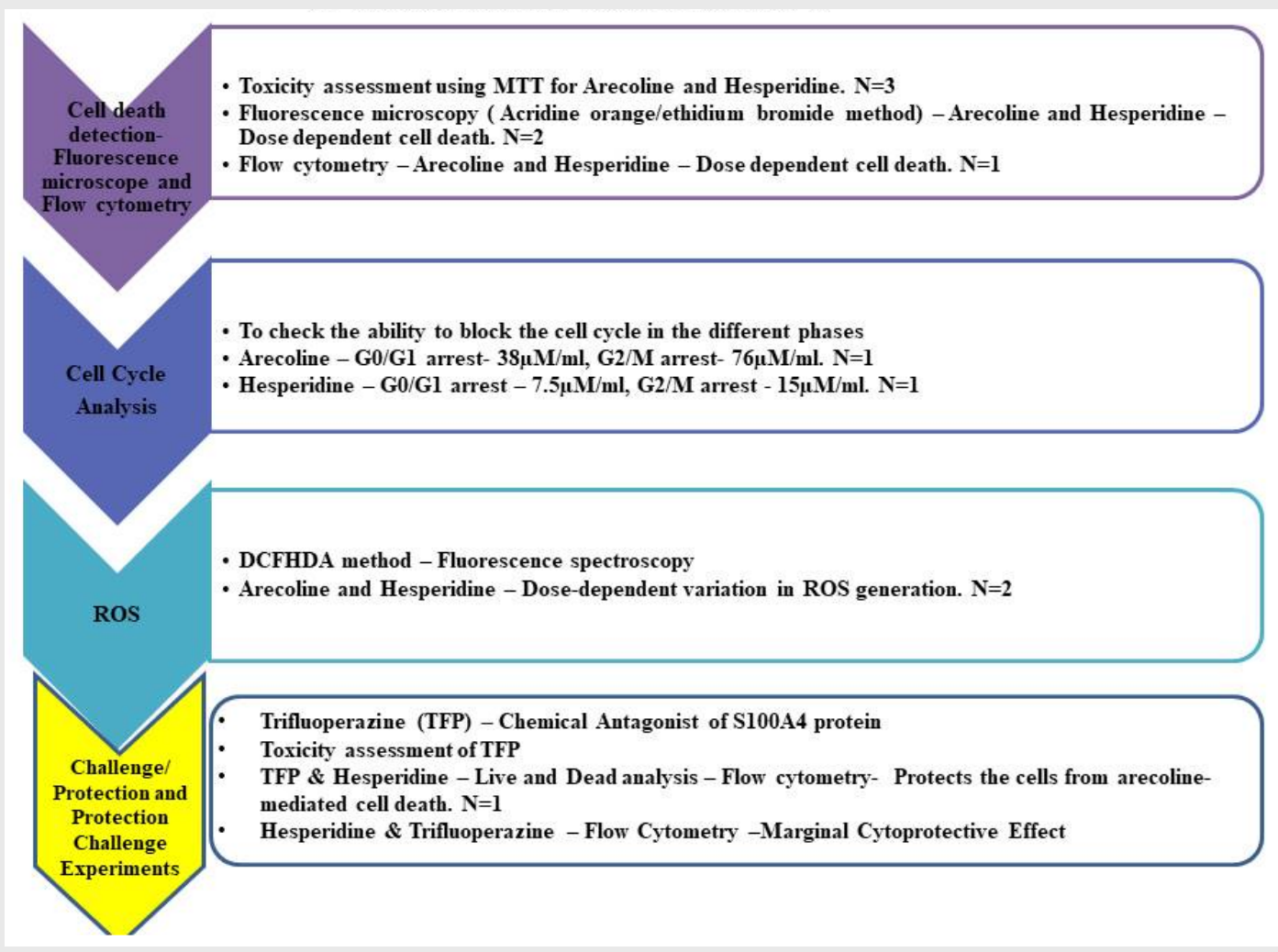

About Authors

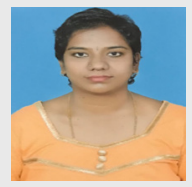

Vembuli A Varadharaj: She has completed her Bachelor as well as her Master of Science degrees in Microbiology. She has worked with Rotavirus and Enteroviruses for 3 years at the Department of Microbiology and Cell Biology (MCB), Indian Institute of Science, Bangalore. Currently, she is a Ph.D researcher at VIT, Vellore and is working on an arecoline-mediated cell death in NIH/3T3 cells and evaluating the possible role of S100A4 in this process.

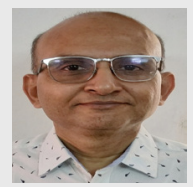

P.K.Suresh: $\mathrm{He}$ is a Professor Higher Academic Grade (PHAG) in the Department of Biomedical Sciences, School of Biosciences and Technology. He has approximately 20.5 years of teaching, research and administrative experience (post-Ph.D.). He received his second masters and Ph.D. in SIUE, IL, USA and the University of Cincinnati, Ohio, USA respectively. He was a Postdoctoral fellow at the University of Texas at Austin, TX, USA as well as Rutgers University, Piscataway, USA. P.K. Suresh has authored/co-authored 48 publications in SCOPUS-indexed journals with an h-index of 11 and a cumulative citation index of 434 . He has been a resource person and/ or coordinator in several Faculty Development Programs as well as in International Conferences in India and overseas. He has mentored students at several levels including those pursuing their doctoral degree. Apart from in silico and in vitro Chemical Biology/Technology, he is also involved in drug development and delivery systems.

Cite this article: Varadharaj VA, Suresh PK. Arecoline, Hesperidin and Trifluoperazine-mediated Cytotoxicity and Cell Death Potential in NIH/3T3 Fibroblasts Cells -Toxicity/Safety Assessment in a NIH/3T3 Model Fibroblast Cell Line. Indian J of Pharmaceutical Education and Research. 2020;54(3s):s537-s551. 